This is an open access article distributed under the terms of the Creative Commons BY-NC-ND Licence

\title{
Suitable reference genes for real-time quantitative PCR in Salsola laricifilia under five abiotic stresses
}

\author{
Y.-F. ZHANG ${ }^{1}$, Z.-B. WEN ${ }^{1 *}$, Y. WANG ${ }^{1,2}$, Y.-L. WANG ${ }^{1,2}$, and Y. FENG ${ }^{1}$ \\ Key Laboratory of Biogeography and Bioresource in Arid Land, Xinjiang Institute of Ecology and Geography, Chinese \\ Academy of Sciences, Urumqi, 830011, P.R. China ${ }^{1}$ \\ University of Chinese Academy of Sciences, Beijing, 100049, China ${ }^{2}$
}

\begin{abstract}
Salsola laricifolia, a typical $\mathrm{C}_{3}-\mathrm{C}_{4}$ intermediate desert plant, is an important for understanding gene evolution and mechanisms for drought resistance. The reverse transcription quantitative polymerase chain reaction (RT-qPCR) is a preferred choice for gene expression studies, but it requires stable reference genes for normalization. Therefore, we tested the expression stability of five candidate reference genes in S. laricifolia: EF1 $\alpha$ (elongation factor 1- $\alpha$ ), ACT (actin), GAPDH (glyceraldehyde-3-phosphate dehydrogenase), TUB (tubulin), and 18S (18S ribosomal RNA). The expressions were tested in different tissues and under five stresses caused by abscisic acid (ABA), $\mathrm{NaCl}, \mathrm{NaHCO}_{3}$, darkness, and osmotic stress (polyethylene glycol 6000, PEG). Four commonly used software programs (geNorm, NormFinder, BestKeeper, and RefFinder) were used. The results show the following most stable reference genes: GAPDH for ABA and dark treatments; EFla for $\mathrm{NaCl}$, PEG; and all samples; $T U B$ for $\mathrm{NaHCO}_{3}$; and $18 S$ for the controls. The $A C T$ was not ranked first in any group, and was the least stable reference gene under the dark, $\mathrm{NaHCO}_{3}$, and PEG. Moreover, pairwise analysis by the geNorm algorithm shows that two best reference genes were $18 S$ and $E F 1 a$ for the controls, GAPDH, and $18 S$ for the ABA and dark treatments, EFla and TUB for the $\mathrm{NaCl}$ treatment, TUB and $18 \mathrm{~S}_{\text {for }}$ the $\mathrm{NaHCO}_{3}$ treatment, EFla and GAPDH for the PEG treatment, and EFla and $18 S$ for all samples. The reference genes for RT-qPCR in S. laricifolia identified in our study will facilitate future work on targeted gene expression.
\end{abstract}

Additional key words: abscisic acid, $\mathrm{C}_{3}-\mathrm{C}_{4}$ intermediate species, $\mathrm{NaCl}, \mathrm{NaHCO}_{3}$, polyethylene glycol, RT-qPCR normalization.

\section{Introduction}

Gene expression analysis has contributed to better understanding the characteristics and functions of targeted genes. There are three commonly used methods for analyzing gene expression: northern blotting, semiquantitative reverse transcription-PCR, and reverse transcription quantitative real-time PCR (RT-qPCR) (Bustin et al. 2009). Among these, RT-qPCR is a preferred choice because of its high sensitivity, accuracy, highthroughput capability, and low-cost (Bustin 2000, Huggett

et al. 2005). However, it is necessary to utilize a normalization method to correct for the variations resulting from experimental procedures such as the quality and quantity of the mRNA template, reverse transcription efficiency, and PCR efficiency (Vandesompele et al. 2002, Udvardi et al. 2008, Guénin et al. 2009). The RT-qPCR data must be normalized with at least one stable reference gene (Chen et al. 2011). Some reports have even suggested that at least two reference genes should be combined

Submitted 15 May 2018, last revision 28 November 2018, accepted 29 November 2018.

Abbreviations: $18 S$ - 18S ribosomal RNA; ABA - abscisic acid; ACT - actin; cDNA - complementary DNA; Cq values - quantification cycles; CV - coefficient of variance; $C Y C$ - cyclophilin; EF1 $\alpha$ - elongation factor 1-alpha; GAPDH - glyceraldehyde-3-phosphate dehydrogenase; ICGs - internal control genes; KLCs - Kranz-like cells; M value - the expression stability value; PEG - polyethylene glycol 6000; RPL - ribosomal phosprotein large; RPS - ribosomal protein S; RT-qPCR - reverse transcription real-time quantitative PCR; TIP41 - TIP41-like family protein; TUB - tubulin; UBI - ubiquitin, $\mathrm{V}_{\mathrm{n}} / \mathrm{n}+1$ - pairwise variation.

Acknowledgements: This work was supported by the Natural Science Foundation in China (grant Nos. 31670339 and 31770227 ) and the Special Funds for the Young Scholars of Taxonomy of the Chinese Academy of Sciences (No. ZSBR-007). The first two authors contributed equally to this work.

* Corresponding author: fax: (+86) 991 7885320, e-mail: zhibinwen@ms.xjb.ac.cn 
together to normalize the RT-qPCR data (Hong et al. 2008).

Reference genes are usually housekeeping genes expressed universally in all cells (Bustin 2002) such as elongation factor 1- $\alpha$ (EF1 $\alpha)$, actin (ACT), glyceraldehyde-3-phosphate dehydrogenase (GAPDH), and tubulin $(T U B)$. However, these traditional reference genes are not always stably expressed under different conditions (Xiao et al. 2015, Chen et al. 2017). Even for the same plant, reference genes may show different stability patterns under different stresses (Li et al. 2015, Xiao et al. 2015). Therefore, it is necessary to establish suitable reference genes for each species and tested them under certain experimental conditions in order to ensure their stability (Li et al. 2012, 2013, Zhao et al. 2016, Acevedo et al. 2017, Chen et al. 2017). So far, suitable reference genes have been selected in a variety of model plants, such as Arabidopsis thaliana (Czechowski et al. 2005), rice (Kim et al. 2003), and tomato (Expósito-Rodríguez et al. 2008), as well as in crops, such as cotton (Wang et al. 2013), wheat (Paolacci et al. 2009), soybean (Jian et al. 2008); fruit trees, such as apple (Perini et al. 2014) and banana (Chen et al. 2011); flowers, such as rose (Klie and Debener 2011) and petunia (Mallona et al. 2010); grasses, such as Eleusine indica (Chen et al. 2017) and Saliconia europaea (Xiao et al. 2015); woody plants, such as Eremosparton songoricum (Li et al. 2012) and poplar (Brunner et al. 2004); and a moss Syntrichia caninervis (Li et al. 2015). The development of next-generation sequencing technologies can be used to explore the genetic resources of more plants (Hong et al. 2010, Demidenko et al. 2011, Feng et al. 2013). To evaluate the most stable reference genes of a particular species under given experimental conditions, several statistical algorithms, such as geNorm (Vandesompele et al. 2002), NormFinder (Andresen et al. 2004), BestKeeper (Pfaffl et al. 2004), and RefFinder (Xie et al. 2012) have been used.

Salsola laricifolia (Chenopodiaceae), is a $\mathrm{C}_{3}-\mathrm{C}_{4}$ intermediate desert species (Wen and Zhang 2015b), which is mainly distributed from east Kazakhstan and Kyrgyzstan to northern China and Mongolia (Wen et al. 2014). The $\mathrm{C}_{3}-\mathrm{C}_{4}$ intermediate species have anatomical and photosynthetic characteristics intermediate between

\section{Materials and methods}

In our experiment, the seeds of Salsola laricifolia Litv. ex. Drobow were collected from Toli City (Xinjiang, China). Seeds were stored at $4{ }^{\circ} \mathrm{C}$ before being germinated on moist paper at room temperature. The seeds were then placed in a growth chamber (a relative humidity of approximately $50 \%$, day/night temperatures of $25 / 18{ }^{\circ} \mathrm{C}$, a 14-h photoperiod, and an irradiance of $400 \mu \mathrm{mol} \mathrm{m}^{-2} \mathrm{~s}^{-1}$ ). Then, two-week-old seedlings were transplanted to $9 \mathrm{~cm}$ diameter pots with a Hoagland solution. Each pot had a float with eight holes and contained eight plants; the those of $\mathrm{C}_{3}$ and $\mathrm{C}_{4}$ plants (Ueno 2011). For example, S. laricifolia has near-continuous and distinctive Kranzlike cells (KLCs), a relatively low $\mathrm{CO}_{2}$ compensation point (30.4 $\mu \mathrm{mol} \mathrm{mol} \mathrm{m}^{-1}$ ), mitochondria in KLCs primarily occurring along the centripetal wall, and, importantly, P-protein glycine decarboxylase is located in the KLCs (Wen and Zhang 2015b). The $\mathrm{C}_{3}-\mathrm{C}_{4}$ species are of a special interest because they may help to elucidate $\mathrm{C}_{4}$ evolution and its mechanisms for reduction of photorespiration (Edwards and $\mathrm{Ku}$ 1987). Until now, no comprehensive study has been performed to evaluate stable reference genes for $\mathrm{C}_{3}-\mathrm{C}_{4}$ intermediate species in response to abiotic stresses. The $\beta$ - $A C T$ has been utilized as an RT-qPCR reference gene in $S$. laricifolia under soil drought (Wen and Zhang 2015a). Therefore, a systematic selection of stable reference genes for $S$. laricifolia is necessary and will be helpful for molecular studies using RT-qPCR in the future.

In 2017, a knowledge base of internal control genes (ICGs) for RT-qPCR normalization has been established (http://icg.big.ac.cn/index.php/Main_Page) for a variety of species (Sang et al. 2017a). The top 10 ICGs are mostly traditional reference genes: EFl $\alpha, A C T$, ubiquitin (UBI), $G A P D H$, ribosomal phosprotein large (RPL), TUB, ribosomal protein $S$ (RPS), $18 S$ ribosomal $R N A$ (18S), cyclophilin (CYC), and TIP41-like family protein (TIP41). In the ICG database, more than 70 species have adopted $E F 1 \alpha$ and $A C T$ as reference genes; 50 to 70 species have chosen $U B I$ and $G A P D H ; 30$ to 50 species have adopted $R P L$ and $T U B$; and less than 30 species have chosen RPS, 18S, CYC, and TIP41. After considering the top $10 \mathrm{ICG}$ ranking and the total number of species adopting them, we have selected commonly preferred candidate reference genes (EFla, ACT, GAPDH, TUB, and 18S). The expression stabilities of these five candidate genes were evaluated in S. laricifolia subjected to non-stress (control) conditions and to polyethylene glycol 6000 (PEG), NaCl, $\mathrm{NaHCO}_{3}$, abscisic acid (ABA), and dark treatments, and data were analyzed by the four most commonly used algorithms (geNorm, NormFinder, BestKeeper, and RefFinder) to determine sets of candidate reference genes suitable for gene expression studies in this species.

Hoagland solution was changed weekly. Irradiance was increased to $1000 \mu \mathrm{mol} \mathrm{m} \mathrm{m}^{-2} \mathrm{~s}^{-1}$. Two-month-old plants were subjected to various abiotic stresses. All treatments started at $2 \mathrm{~h}$ after the beginning of a photoperiod. The Hoagland solution with $0,50,100,150$, and $200 \mu \mathrm{M}$ ABA or with $0,50,100,150$, and $200 \mathrm{mM} \mathrm{NaCl}$ or with 0,15 , 30,45 , and $60 \mathrm{mM} \mathrm{NaHCO} 3$ or with $0,10,20,30,40,50$, and $60 \%(\mathrm{~m} / \mathrm{v})$ PEG were applied for $4 \mathrm{~h}$. For dark treatment, the pots were covered for $0,0.5,1,2,6$, and $12 \mathrm{~h}$. Leaves and roots were all collected immediately, 
frozen in liquid nitrogen, and stored at $-80^{\circ} \mathrm{C}$ until used. Each treatment had four biological replicates.

Total RNA was isolated from $100 \mathrm{mg}$ of frozen leaves using a TransZol reagent (Transgen Biotech, Beijing, China) (four independent extractions for each treatment) following the manufacturer's instructions. Any contaminated genomic DNA was removed by treatment with an RNase-free DNase kit (Qiagen, Valencia, USA). The total RNA concentration and purity were determined using a NanoDrop ND-2000 spectrophotometer (Thermo Fisher Scientific, San Jose, USA). The RNA samples with absorption ratios of $\mathrm{A}_{260} / \mathrm{A}_{280}=1.8-2.2$ and $\mathrm{A}_{260} / \mathrm{A}_{230}$ higher than 2.0 were used for subsequent complementary DNA synthesis. The integrity was verified by $1.5 \%(\mathrm{~m} / \mathrm{v})$ agarose gel electrophoresis. The first-strand cDNA was synthesized using a Reversal Transcription Reagent kit (Takara, Tokyo, Japan) following the manufacturer's instructions.

Based on the top ten ICG ranking and the total number of species adopting them, we chose five candidate reference genes ( $E F 1 \alpha, A C T, G A P D H, T U B$, and $18 S$ ). The five genes retrieved from the transcriptome database of $S$. laricifolia were cloned, and the obtained sequences were highly homologous to the gene sequences registered by the National Center for Biotechnology Information. Reverse transcription qPCR primers were designed with Primer Premier v. 5.0 using the following criteria: an amplicon length ranged from 100 to $300 \mathrm{bp}$ and melting temperature $\left(\mathrm{T}_{\mathrm{m}}\right)$ from 55 to $61{ }^{\circ} \mathrm{C}$ (Table 1 Suppl.). All RT-qPCR experiments conformed to the $M I Q E$ guideline (Bustin et al. 2009). The primer specificity was judged by melting-curve analysis and agarose gel electrophoresis of the amplification product. Amplification efficiency was assessed using a standard curve generated by RT-qPCR using a 10-fold dilution series over at least four dilution points that were evaluated in triplicate.

For RT-qPCR, the cDNA was diluted five times and reactions were carried out in 96-well plates with a $C F X 96$ real-time PCR detection system (Bio-Rad, Hercules, USA) using SYBR Premix Ex Taq ${ }^{\mathrm{TM}}$ (Takara). The RT-qPCR was conducted in a reaction mixture containing $4 \mathrm{~mm}^{3}$ of diluted cDNA (1:5), $0.5 \mathrm{~mm}^{3}$ of each of forward and reverse primers $(10 \mu \mathrm{M}), 10 \mathrm{~mm}^{3}$ of real-time master mix, and $5 \mathrm{~mm}^{3}$ of PCR-grade water. Conditions for amplification of RT-qPCR were: polymerase activation at $95^{\circ} \mathrm{C}$ for $30 \mathrm{~s}$ and 40 cycles, each cycle including $95^{\circ} \mathrm{C}$ for $30 \mathrm{~s}, 55^{\circ} \mathrm{C}$ for $10 \mathrm{~s}$, and $72{ }^{\circ} \mathrm{C}$ for $15 \mathrm{~s}$. All samples were run with two technical replicates, and three notemplate controls (replacing the template product with PCR-grade water) were included in every run to monitor possible DNA contamination.

To assess the stability of the five candidate genes, three publicly available software programs geNorm, NormFinder, and BestKeeper were used (Vandesompele et al. 2002, Anderson et al. 2004, Pfaffl et al. 2004). Additionally, a web-based tool RefFinder (http://150.216.56.64/referencegene.php\#) was selected to generate a comprehensive ranking for the candidate reference genes by comparing the results obtained using three programs. The quantification cycles (Cq values) of all reference genes used in geNorm and NormFinder were converted into relative quantities according to a formula $2^{-\Delta \mathrm{Ct}}(\Delta \mathrm{Ct}$ - the corresponding $\mathrm{Cq}$ value - minimum $\mathrm{Cq}$ ) (Livak and Schmittgen 2001). In the geNorm program, two parameters including the expression stability value (M value) and the pairwise variation $\left(\mathrm{V}_{\mathrm{n}} / \mathrm{n}+1\right)$ were used to assess the appropriate reference genes. The recommended threshold of the $\mathrm{M}$ value is below 1.5 (Vandesompele et al. 2002). The $\mathrm{V}_{\mathrm{n}} / \mathrm{V}_{\mathrm{n}+1}$ was analyzed to determine the optimal number of reference genes for accurate normalization. The cut-off value was proposed to be 0.15 . If $\mathrm{V}_{\mathrm{n}} / \mathrm{n}+1<0.15$, the minimal number of best reference genes for accurate normalization should be n; otherwise it should be $\mathrm{n}+1$ (Vandesompele et al. 2002). The NormFinder program calculated the expression stability of the reference genes by combing the intra- and inter-group variations. The lowest stability value indicates the most stable expression within the gene set examined. Raw $\mathrm{Cq}$ values were directly analyzed by the BestKeeper and RefFinder programs. RefFinder generated the final overall ranking based on the geometric mean of the weights of every gene calculated by each program.

All statistical tests were performed with SPSS v. 19.0 (SPSS Inc., Chicago, USA) using a one-way analysis of variance $(A N O V A)$.

\section{Results}

Total RNA from 256 different plant materials was extracted. The RNA quality was checked by $1.5 \%(\mathrm{~m} / \mathrm{v})$ agarose gel electrophoresis. All selected samples showed both $28 \mathrm{~S}$ and $18 \mathrm{~S}$ ribosomal RNA bands with a density ratio of about 2.0 (Fig. 1 Suppl.). The $\mathrm{A}_{260} / \mathrm{A}_{280}$ ratio ranged from 2.0 to 2.2 , and the $\mathrm{A}_{260} / \mathrm{A}_{230}$ ratio was higher than 2.0 for all selected samples. The concentration of total RNA ranged from 245 to $986 \mu \mathrm{g} \mathrm{g}^{-1}$ (f.m.). All sequences of the reference genes were reconfirmed by the PCR

results. All primer sets were $B L A S T$ searched against the non-redundant database in NCBI (primer-BLAST program) as well as the local $S$. laricifolia transcriptome data in order to verify their specificity. Primers for five sequences were confirmed for amplification specificity by gel electrophoresis (Fig. 2 Suppl.). Then, the designed primers were detected by qPCR. For each gene, the melting curve had a single peak (Fig. 3 Suppl.). A PCR amplification efficiency for five references genes varied from 95.3 for 
$A C T$ to 104.1 for $18 S$, and correlation coefficient $\left(R^{2}\right)$ values ranged from 0.9862 to 0.9991 over $10^{5}$ times cDNA dilution (Table 1 Suppl.).

The expressions of five candidate reference genes were determined as $\mathrm{Cq}$ values. According to the box-plot, the $\mathrm{Cq}$ values of the five reference genes ranged from 5.93 to 33.57. The mean $\mathrm{Cq}$ values for the reference genes ranged from 8.29 to 29.65 . The average $\mathrm{Cq}$ value of all the test samples was 20.76 cycles (Fig. 1). The GAPDH had the highest median $\mathrm{Cq}$ value (28.97) indicating a relatively low expression. In contrast, the gene $18 S$ was highly expressed compared with other reference genes (median Cq value $=8.57$ ), corresponding to a high expression. Even for the same reference gene, gene expression varied across different $S$. laricifolia samples. The results indicate that no individual gene showed a constant expression under all the experimental conditions.

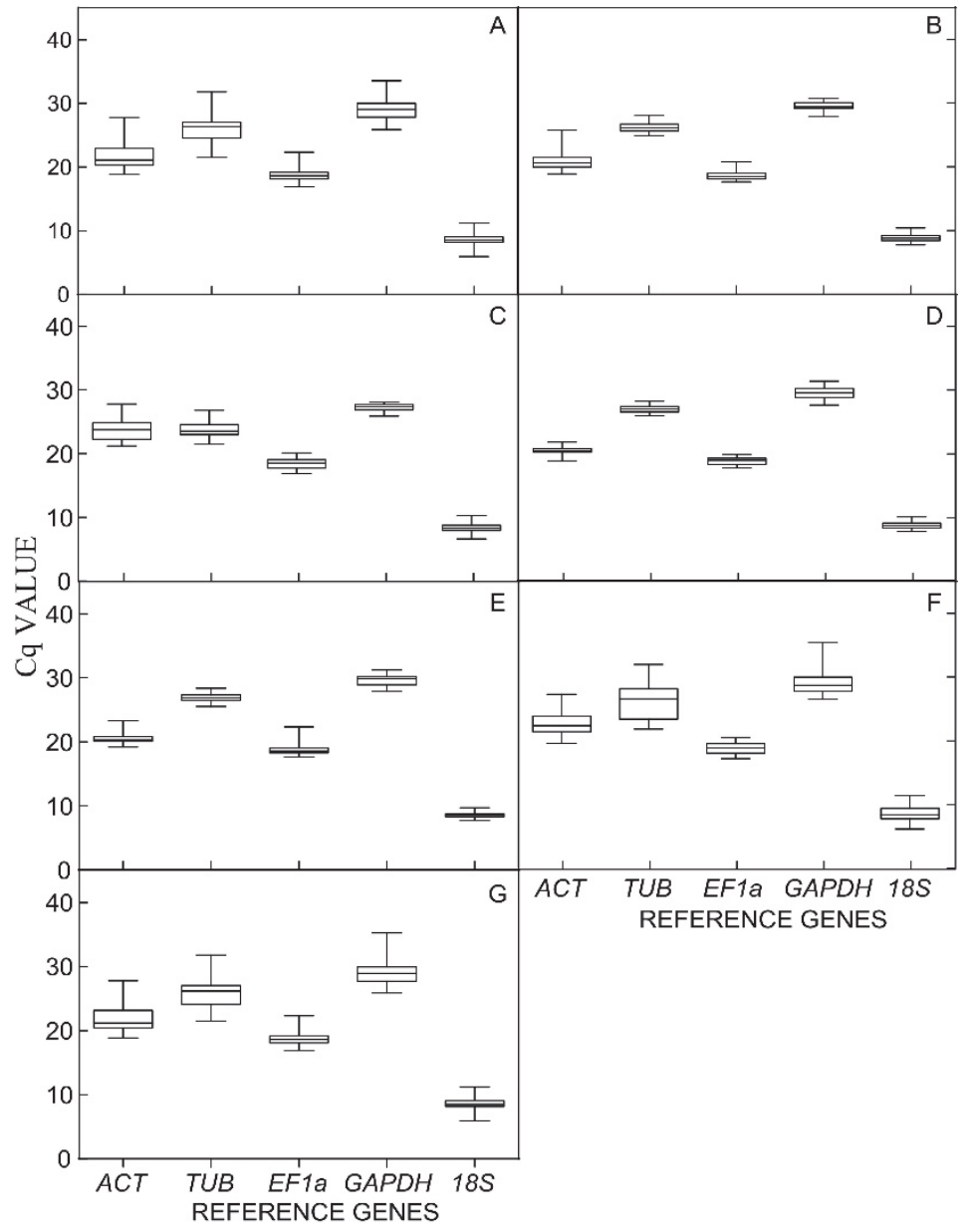

Fig 1. Expressions of reference genes tested under different experimental conditions. $A$ - Controls; $B$ - abscisic acid; $C$ - dark stress; $D$ - NaCl; $E-\mathrm{NaHCO}_{3} ; F$ - polyethylene glycol 6000; $G$ - average of all samples (for each stress, it contained the data across all of the concentrations). The box-plot contains the mean, interquartile range, non-outlier range, and outlier, $n=4$. ACT - actin; TUB - tubulin; EFlá - elongation factor 1-alpha; GAPDH - glyceraldehyde-3-phosphate dehydrogenase; 18S - 18S ribosomal RNA.

To obtain a reliable dataset of the optimal reference genes for the six sample groups, the expressions of five candidate genes were analyzed and ranked using geNorm, NormFinder, BestKeeper, and RefFinder individually. In the geNorm, two parameters including the $\mathrm{M}$ value and $\mathrm{V}_{\mathrm{n}} / \mathrm{n}+1$ were used to assess the appropriate reference genes. Each candidate reference gene had an $M$ value less than 1.5 (Table 2 Suppl.). In the control, $18 S$ ranked as the most stable gene, whereas $T U B$ was considered the least stable gene. Under the treatments with $\mathrm{ABA}$ and darkness, $G A P D H$ was the most stable gene, whereas $A C T$ was least stable. For all the tested samples and the conditions of $\mathrm{NaCl}$ and PEG treatments, the most stable gene was the same (EFla). The TUB ranked as the most stable gene under the $\mathrm{NaHCO}_{3}$ treatment set. The $A C T$ was considered the least stable gene (Table 2 Suppl). The RT-qPCR data were classified into seven groups (all samples, ABA, dark, $\mathrm{NaCl}, \mathrm{NaHCO}_{3}, \mathrm{PEG}$, and controls), their pairwise variation $\left(\mathrm{V}_{2 / 3}\right)$ being $0.028,0.019,0.032,0.015,0.015$, 0.029 , and 0.125 , respectively (Fig. 2). Based on the rule of pairwise variation (Vandesompele et al. 2002), two of the best reference genes were used to determine the 
optimal number of reference genes for each group: $18 S$ and EFla for the control group, GAPDH and $18 S$ for the dark treatment, EFl $a$ and $T U B$ for the $\mathrm{NaCl}$ treatment, TUB and $18 S$ for the $\mathrm{NaHCO}_{3}$ treatment, EFI $a$ and $G A P D H$ for the PEG and ABA treatments, and EFla and $18 S$ for all samples (Table 2 Suppl.).

According to the NormFinder, a lower stability value indicates the most stable expression for RT-qPCR (Andersen et al. 2004). The results of stable value ranking are shown in Table 2 Suppl. for each group. The most and least stable reference genes were the same as in the results evaluated by geNorm with the exception of the least stable gene in the ABA group ( $A C T$ determined by geNorm, whereas $18 S$ by the NormFinder).

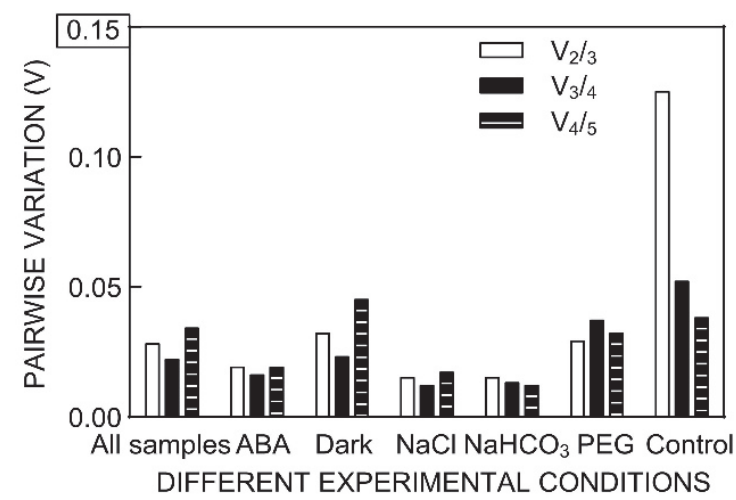

Fig 2. Pairwise variation $\left(\mathrm{V}_{\mathrm{n}} / \mathrm{V}_{\mathrm{n}+1}\right)$ analysis for selecting optimal number of reference genes in normalization of Salsola laricifolia with the geNorm algorithm.

\section{Discussion}

In this work, we have focused on S. laricifolia, an important $\mathrm{C}_{3}-\mathrm{C}_{4}$ intermediate desert plant (Wen and Zhang 2015b). We have used RT-qPCR analysis to search for stable reference genes as their knowledge in S. laricifolia lagged behind that for other major plant groups.

The housekeeping genes $A C T, 18 S$, and $G A P D H$, are frequently used for RT-qPCR normalization (Sang et al. 2013). However, some studies suggest that new reference genes could be more stably expressed than these ones under specific conditions (e.g., Czechowski et al. 2005, Libault e al. 2008, Li et al. 2015, Liu et al. 2017). Therefore, the selection of candidate reference genes is important. The $I C G$ is a useful base of reference genes for RT-qPCR normalization in many species including both model and non-model organisms (Sang et al. 2017a). Taking into account the top 10 ICG ranking and the total number of species adopting them, we chose five preferred candidate reference genes for this study (EF1 $\alpha, A C T$, GAPDH, TUB, and 18S).

We compared analyses done by geNorm and NormFinder and found these programs consistent in the ranking of the reference genes under most treatments except under the ABA. Under the ABA treatment, the most
In BestKeeper, the coefficient of variance (CV) and the standard deviation (SD) of candidate genes were calculated to evaluate the stability of each group. The lowest $\mathrm{SD}$ and $\mathrm{CV}$ values suggest the most stable reference gene (Chang et al. 2012). The most stable reference gene based on BestKeeper analysis was the same as with geNorm and NormFinder in the control, dark, and PEG treatments. In the ABA set, EFla was the most stable gene $(\mathrm{SD}=0.56)$, whereas $18 S$ was the least stable gene $(\mathrm{SD}=1.51)$. For $\mathrm{NaCl}$ treatment, $A C T$ was the most stable gene $(\mathrm{SD}=0.42)$, whereas $G A P D H$ was the least stable gene $(\mathrm{SD}=0.82)$. For the $\mathrm{NaHCO}_{3}$ group, $18 S$ was the most stable gene $(\mathrm{SD}=0.26)$, whereas $G A P D H$ was the least stable gene $(\mathrm{SD}=0.69)$.

To address the heterogeneity of the results evaluated using geNorm, NormFinder, and BestKeeper, RefFinder has been recommended (Xie et al. 2012). This would represent a comprehensive ranking of the gene expression stability. The most stable reference gene suggested by RefFinder in these seven treatments was the same as in the results evaluated by the geNorm and NormFinder. The ranking of five reference genes was similar to the NormFinder. Based on the results of RefFinder, $18 S$ was the most stable gene in the control (1.57), whereas $T U B$ was the least stable gene (4.73). Under treatment with ABA and the dark, GAPDH was the most stable gene. For the $\mathrm{NaCl}$, and PEG groups, EF $1 a$ was the most stable gene, and for the $\mathrm{NaHCO}_{3}$ group, $T U B$ was the most stable gene (1.41), whereas $A C T$ was the least stable gene (4.23) (Table 2 Suppl.).

stable reference gene suggested by these two analyses was $G A P D H$, but the gene ranking and the least stable reference gene were different (Table 2 Suppl.). The results from BestKeeper analysis were similar to those from geNorm and NormFinder in the control, dark, and PEG groups, and when all samples were considered. However, there were differences for $\mathrm{ABA}, \mathrm{NaCl}$, and $\mathrm{NaHCO}_{3}$ treatments similarly as has been found in other studies (Petriccione et al. 2015, Zhang et al. 2017). Based on the above results, a fourth algorithm (RefFinder) was used to overcome the differences among geNorm, NormFinder, and BestKeeper to obtain the final choice of reference genes. The genes ranking first were $G A P D H$ in ABA and the dark group; EFla in NaCl, PEG, and all samples; $T U B$ in the $\mathrm{NaHCO}_{3}$ group; and $18 \mathrm{~S}$ in the control. These have the lowest geometric mean and ranked first in geNorm, NormFinder, and BestKeeper except in the $\mathrm{NaCl}$ and $\mathrm{NaHCO}_{3}$ sets. The ranked first gene was suggested the most stable gene in the corresponding group.

Previous studies suggested that RT-qPCR data must be normalized with at least one stable reference gene (Chen et al. 2011), and some reports have even stated that at least two reference genes should be combined to normalize the 
RT-qPCR data (Hong et al. 2008). Pairwise variation $\left(\mathrm{V}_{\mathrm{n}} / \mathrm{n}+1\right)$ in geNorm was used to assess the appropriate reference genes. The RT-qPCR data were classified into seven groups (all samples, ABA, dark, $\mathrm{NaCl}, \mathrm{NaHCO}_{3}$, PEG, and control), with pairwise variation $\left(\mathrm{V}_{2 / 3}\right)$ below 0.15 (Fig. 2). Based on the rule of pairwise variation (Vandesompele et al. 2002), we suggested two best reference genes as the optimal number of reference genes for each group, the choices being $18 S$ and EFla for the control, GAPDH and $18 S$ for the ABA and dark treatments, $E F l a$ and $T U B$ for the $\mathrm{NaCl}$ treatment, $T U B$ and $18 S$ for the $\mathrm{NaHCO}_{3}$ treatment, EFla and GAPDH for the PEG treatment, and EFIa and $18 S$ for all samples (Table 2 Suppl.).

Our results show that EFIa, ranked first in the top 10 IGCs, was a reliable reference gene in $\mathrm{NaCl}, \mathrm{PEG}$, and all samples (Table 2 Suppl.) and ranked second or third in other treatments. The EFIa has also been found to be a stable reference gene in Atractylodes lancea under drought stress (Sang et al. 2017b), Glycine max under drought and salinity stresses (Ma et al. 2013), Caragana korshinskii under heat stress (Yang et al. 2014), and creeping bentgrass under cold stress (Chen et al. 2015). Only in the control, $18 S$ was a reliable reference gene, and only in the $\mathrm{NaHCO}_{3}$ group, $T U B$ was a reliable reference gene. But $18 S$ and $T U B$ exhibited high variations under other experimental conditions (Table 2 Suppl.). The reference gene $A C T$, ranking second in the top $10 \mathrm{IGCs,} \mathrm{we} \mathrm{found} \mathrm{to}$ be the least stable reference gene in the dark, $\mathrm{NaHCO}_{3}$, and PEG groups (Table 2 Suppl.), which is consistent with Populus across developmental stages (Xu et al. 2011). However, $A C T$ has been found to be a stable gene in Salicornia europaea under drought stress and nitrogen treatment (Xiao et al. 2015), and in the root of Cunninghamia lanceolata (Bao et al. 2016). Different studies have yielded inconsistent results because reference genes have been evaluated under different conditions for the same species or in different plant species. Sometimes tested reference genes with the same names actually belong to multigene families. This could be one of the sources of variations in the published studies (Oakley et al. 2007). Therefore, it is important to choose suitable reference genes for each species and tested them under certain experimental conditions (Li et al. 2012, 2013, Zhao et al. 2016, Chen et al. 2017).

\section{References}

Acevedo, R.M., Avico, E.H., Ruiz, O.A., Sansberro, P.A.: Assessment of reference genes for real-time quantitative PCR normalization in Ilex paraguariensis leaves during drought. Biol. Plant. 62: 89-96, 2018.

Andersen, C.L., Jensen, J.L., Ørntoft, T.F.: Normalization of real-time quantitative reverse transcription-PCR data: a model-based variance estimation approach to identify genes suited for normalization, applied to bladder and colon cancer data sets. - Cancer Res. 64: 5245-5250, 2004.

Bao, W., Qu, Y., Shan, X., Wan, Y.: Screening and validation of housekeeping genes of the root and cotyledon of Cunninghamia lanceolata under abiotic stresses by using quantitative real-time PCR. - Int. J mol. Sci. 17: E1198, 2016.

Brunner, A.M., Yakovlev, I.A., Strauss, S.H.: Validating internal controls for quantitative plant gene expression studies. BMC Plant Biol. 4: 14, 2004.

Bustin, S.A.: Absolute quantification of mRNA using real-time reverse transcription polymerase chain reaction assays. - J. mol. Endocrinol. 25: 169-193, 2000.

Bustin, S.A.: Quantification of mRNA using real-time reverse transcription PCR (RT-PCR): trends and problems. - J. mol. Endocrinol. 29: 23-39, 2002.

Bustin, S.A., Benes, V., Garson, J.A., Hellemans, J., Huggett, J., Kubista, M., Mueller, R., Nolan, T., Pfaffl, M.W., Shipley, G.L., Vandesompele, J., Wittwer, C.T.: The MIQE guidelines: minimum information for publication of quantitative real-time PCR experiments. - Clin. Chem. 55: 611-622, 2009.

Chang, E., Shi, S.Q., Liu, J.F., Cheng, T.L., Xue, L., Yang, X. Y., Yang, W.J., Lan, Q., Jian, Z.P.: Selection of reference genes for quantitative gene expression studies in Platycladus orientalis (Cupressaceae) using real-time PCR. - PloS ONE 7: e33278, 2012.
Chen, J.C., Huang, Z.F., Huang, H.J., Wei, S.H., Liu, Y., Jiang, C.L., Zhang, J., Zhang, C.X.: Selection of relatively exact reference genes for gene expression studies in goosegrass (Eleusine indica) under herbicide stress. - Sci. Rep. 7: 46494, 2017.

Chen, L., Zhong, H.Y., Kuang, J.F., Li, J.G., Lu, W.J., Chen, J.Y.: Validation of reference genes for RT-qPCR studies of gene expression in banana fruit under different experimental conditions. - Planta 234: 377-390, 2011.

Chen, Y., Hu, B.Y., Tan, Z.Q., Liu, J., Yang, Z.M., Li, Z.H., Huang, B.R.: Selection of reference genes for quantitative real-time PCR normalization in creeping bentgrass involved in four abiotic stresses. - Plant Cell Rep. 34: 1825-1834, 2015.

Czechowski, T., Stitt, M., Altmann, T., Udavardi, M.K., Scheibe, W.R.: Genome-wide identification and testing of superior reference genes for transcript normalization in Arabidopsis. Plant Physiol. 139: 5-17, 2005.

Demidenko, N.V., Logacheva, M.D., Penin, A.A.: Selection and validation of reference genes for quantitative real-time PCR in buckwheat (Fagopyrum esculentum) based on transcriptome sequence data. - PLoS ONE 6: e19434, 2011.

Edwards, G.E., Ku, M.S.B.: Biochemistry of $\mathrm{C}_{3}-\mathrm{C}_{4}$ intermediates. - In Hatch, M.D, Boardman, N.K. (ed.): The Biochemistry of Plants. Vol 10. Pp. 275-325. Academic Press, New York 1987.

Expósito-Rodríguez, M., Borges, A.A., Borges-Pérez, A., Pérez, J.A.: Selection of internal control genes for quantitative realtime RT-PCR studies during tomato development process. BMC Plant Biol. 8: 131, 2008.

Feng, L.Y., Yu, Q., Li, X., Ning, X.H, Wang, J., Zou, J.J., Zhang, L.L., Wang, S., Hu, J.J., Xu, X.L., Bao, Z.M.: Identification 
of reference genes for qRT-PCR analysis in yesso scallop Patinopecten yessoensis. - PLoS ONE 8: e75609, 2013.

Guénin, S., Mauriat, M., Pelloux, J., Van Wuytswinkel, O., Bellini, C., Gutierrez, L.: Normalization of qRT-PCR data: the necessity of adopting a systematic, experimental conditions-specific, validation of reference. - J. exp. Bot. 60: 487-493, 2009.

Hong, S.M., Bahn, S.C., Lyu, A., Jung, H.S., Ahn, J.H.: Identification and testing of superior reference genes for a starting pool of transcript normalization in Arabidopsis. Plant Cell Physiol. 51: 1694-1706, 2010.

Hong, S.Y., Seo, P.J., Yang, M.S., Xiang, F., Park, C.M.: Exploring valid reference genes for gene expression studies in Brachypodium distachyon by real-time PCR. - BMC Plant Biol. 8: 112, 2008.

Huggett, J., Dheda, K., Bustin, S., Zumla, A.: Real-time RT-PCR normalization; strategies and considerations. - Genes Immun. 6: 279-284, 2005.

Jian, B., Liu, B., Bi, Y.R., Hou, W.S., Wu, C.X., Han, T.F.: Validation of internal control for gene expression study in soybean by quantitative real-time PCR. - BMC mol. Biol. 9: 59, 2008.

Kim, B.R., Nam, H.Y., Kim, S.U., Kim, S.I., Chang, Y.J.: Normalization of reverser transcription quantitative-PCR with housekeeping genes in rice. - Biotechnol. Lett. 25: 18691872, 2003.

Klie, M., Debener, T.: Identification of superior reference genes for data normalization of expression studies via quantitative PCR in hybrid roses (Rosa hybrida). - BMC res. Notes 4: $518,2011$.

Li, R.M., Xie, W., Wang, S.L., Wu, Q.J., Yang, N., Pan, H.P., Zhou, X.M., Bai, L. Y., Xu, B.Y., Zhou, X.G., Zhang, Y.J.: Reference gene selection for qRT-PCR analysis in the sweet potato whitefly, Bemisia tabaci (Hemiptera: Aleyrodidae). PLoS ONE 8: e53006, 2013.

Li, X.S., Yang, H.L., Zhang, D.Y., Zhang, Y.M., Wood, A.J.: Reference gene selection in the desert plant Eremosparton songoricum. - Int. J. mol. Sci. 13: 6944-6963, 2012.

Li, X.S., Zhang, D.Y., Li, H.Y., Gao, P., Yang, H.L., Zhang, Y.M., Wood, A.J.: Characteriazation of reference genes for RT-qPCR in the desert moss Syntrichia caninervis in response to abiotic stress and desiccation/rehydration. Front. Plant Sci. 6: 38, 2015.

Libault, M., Thibivilliers, S., Bilgin, D.D., Radwan, O., Benitez, M., Clough, S.J.., Stacey, G.: Identification of four soybean reference genes for gene expression normalization. - Plant Genome 1: 44-54, 2008.

Liu, Y., Liu, J., Xu, L., Lai, H., Chen, Y., Yang, Z.M., Huang, B.R.: Identification and validation of reference genes for seashore Paspalum response to abiotic stresses. - Int. J. mol. Sci. 18: E1322, 2017.

Livak, K.J., Schmittgen, T.D.: Analysis of relative gene expression data using real-time quantitative PCR and the

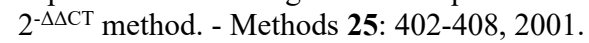

Ma, S.H., Niu, H.W., Liu, C.J., Zhang, J., Hou, C.Y., Wang, D.M.: Expression stabilities of candidate reference genes for RT-qPCR under different stress conditions in soybean. PLoS ONE 8: e75271, 2013.

Mallona, I., Lischewski, S., Weiss, J., Hause, B., Egea-Cortines, M.: Validation of reference genes for quantitative real-time PCR during leaf and flower development in Petunia hybrida. - BMC Plant Biol. 10: 4, 2010.
Oakley, R.V., Wang, Y.S., Ramakrishna, W., Harding, S.A., Tsai, C.J.: Differential expansion and expression of alphaand beta-tubulin gene families in Populus. - Plant Physiol. 145: 961-973, 2007.

Paolacci, A.R., Tanzarella, O.A., Porceddu, E., Ciaffi, M.: Identification and validation of reference genes for quantitative RT-PCR normalization in wheat. - BMC mol. Biol. 10: 11, 2009.

Perini, P., Pasquali, G., Margis-Pinheiro, M., de Oliviera, P.R.D., Revers, L.F.: Reference genes for transcriptional analysis of flowering and fruit ripening stages in apple (Malus $\times$ domestica Borkh.). - Mol. Breed. 34: 829-842, 2014.

Petriccione, M., Mastrobuoni, F., Zampella, L., Scortichini, M.: Reference gene selection for normalization of RT-qPCR gene expression data from Actinidia deliciosa leaves infected with Pseudomonas syringae pv. actinidiae. - Sci. Rep. 5: 16961, 2015.

Pfaffl, M.W., Tichopad, A., Prgomet, C., Neuvians, T.P.: Determination of stable houskeeping genes, differentially regulated target genes and sample integrity: BestKeeperExcel-based tool using pair-wise correlations. - Biotechnol. Lett. 26: 509-515, 2004.

Sang, J., Han, X.J., Liu, M.Y., Qiao, G.R., Jiang, J., Zhou, R.Y.: Selection and validation of reference genes for real-time quantitative PCR in hyperaccumulating ecotype of Sedum alfredii under differernt heavy metals stresses. - PLoS ONE 8: e82927, 2013.

Sang, J., Wang, Z.N., Li, M., Cao, J.B., Niu, G.Y., Xia, L., Zou, D., Wang, F., Xu, X.J., Han, X.J., Fan, J.Q., Yang, Y., Zuo, W.Z., Zhang, Y., Zhao, W.M., Bao, Y.N., Xiao, J.F., Hu, S.N., Hao, L.L., Zhang, Z.: ICG: a wiki-driven knowledgebase of internal control genes for RT-qPCR normalization. - Nucl. Acids Res. 46: D121-D126, 2017a.

Sang, X.H., Gu, W., Chao, J.G., Liu, Q.Z., Jiang, L., Han, Y., Zhou, Y.Z.: Selection of reference genes of Atractylodes lancea and its application in biosynthesis of active ingredients. - Plant Physiol. J. 53: 1680-1686, $2017 \mathrm{~b}$.

Udvardi, M.K., Czechowski, T., Scheible, W.R.: Eleven golden rules of quantitative RT-qPCR. - Plant Cell 20: 1736-1737, 2008.

Ueno, O.: Structural and biochemical characterization of the $\mathrm{C}_{3}-$ $\mathrm{C}_{4}$ intermediate Brassica gravinae and relatives, with particular reference to cellular distribution of Rubisco. - J. exp. Bot. 62: 5347-5355, 2011.

Vandesompele, J., De Preter, K., Pattyn, F., Poppe, B., Van Roy, N., De Paepe, A., Speleman, F.: Accurate normalization of real-time quantitative RT-PCR data by geometric averaging of multiple internal control genes. - Genome Biol. 3: research0034.1-research0034.11, 2002.

Wang, M., Wang, Q.L., Zhang, B.H.: Evaluation and selection of reliable reference genes for gene expression under abiotic stress in cotton (Gossypium hirsutum L.). - Gene 530: 44-50, 2013.

Wen, Z.B., Zhang, M.L.: Reference gene selection for real-time quantitative PCR in Salsola laricifolia under soil drought stress. - Plant Physiol. J 51: 2031-2038, 2015a.

Wen, Z.B., Zhang, M.L.: Salsola laricifolia, another $\mathrm{C}_{3}-\mathrm{C}_{4}$ intermediate species in tribe Salsoleaes (Chenopodiaceae). Photosynth. Res. 123: 33-43, 2015 b.

Wen, Z.B., Zhang, M.L., Meng, H.H.: Salsola arbusculiformis and S. laricifolia (Chenopodiaceae) in China. - Nord. J Bot. 32: 167-175, 2014. 
Xiao, X.L., Ma, J.B., Wang, J.R., Wu, X.M., Li, P.B., Yao, Y.A.: Validation of suitable reference genes for gene expression analysis in the halophyte Salicornia europaea by real-time quantitative PCR. - Front. Plant Sci. 5: 788, 2015.

Xie, F.L., Xiao, P., Chen, D.L., Xu, L., Zhang, B.H.: miRDeepFinder: a miRNA analysis tool for deep sequencing of plant small RNAs. - Plant mol. Biol. 80: 75-84, 2012.

Xu, M., Zhang, B., Su, X.H., Zhang, S.G., Huang, M.R.: Reference gene selection for quantitative real-time polymerase chain reaction in Populus. - Anal. Biochem. 408: 337-339, 2011.

Yang, Q., Yin, J.J., Li, G., Qi, L.W., Yang, F.Y., Wang, R.G., Li G.J.: Reference gene selection for qRT-PCR in Caragana korshinskii Kom. under different stress conditions. - Mol. Biol. Rep. 41: 2325-2334, 2014.

Zhang, Q.L., Zhu, Q.H., Liao, X., Wang, X.Q., Chen, T., Xu, H.T., Wang, J., Yuan, M.L., Chen, J.Y.: Selection of reliable reference genes for normalization of quantitative RT-qPCR from different developmental stages and tissues in amphioxus. - Sci. Rep. 6: 37549, 2017.

Zhao, X.T., Zhang, X.L., Guo, X., B., Li, S.J., Han, L.L., Song, Z.H., Wang, Y.N., Li, J.H., Li, M.J.: Identification and validation of reference genes for qRT-PCR studies of gene expression in Dioscorea opposita. - BioMed Res. Int. 2016: 3089584, 2016. 